Jurnal Ilmu Pengetahuan dan Pengembangan Masyarakat Islam

p-issn: 2085-8833, e-issn: 2797-6963| Vol. 15, No. 1, April, 2021, pp. 11-21

http: http://ejournal.uin-suska.ac.id/index.php/Menara/index

\title{
Pelatihan Identifikasi Anak Berkebutuhan Khusus bagi Guru PAUD melalui Model Konstruktivisme
}

\author{
Ricca Angreini Munthe1, Masyhuri², Indah Puji Ratnani ${ }^{3}$ \\ 1,2,3Universitas Islam Negeri Sultan Syarif Kasim Riau \\ E-mail: ricca.angreini@uin-suska.ac.id
}

\begin{abstract}
Abstrak
Pentingnya mengidentifikasi kebutuhan khusus yang dimiliki oleh anak menjadi perhatian karena akan berdampak terhadap pemilihan dan keberhasilan program Pendidikan anak berkebutuhan khusus (ABK). Adanya komorbiditas dalam setiap klasifikasi kebutuhan khusus menjadi permasalahan sehingga guru harus diberi pengetahuan mengenai berbagaimacam klasifikasi anak berkebutuhan khusus, ciri-cirinya dan pendidikannya. Klasifikasi anak berkebutuhan khusus sangat banyak. Namun, dalam pengabdian ini kami memfokuskan pada beberapa klasifikasi saja yaitu autis, ADHD, dan disleksia. Pengabdi memberikan pengetahuan tersebut kepada guru PAUD di Kecamatan Bangkinang Kota dengan melakukan pretest dan posttest untuk mengukur keefektifan pelatihan ini. Hasil analisis menunjukkan bahwa rerata nilai pretest adalah 3,36 dan hasil post test adalah 5,52 dengan nilai signifikansi 0,000. Hal tersebut menunjukkan bahwa terdapat perbedaan yang signifikan mengenai pengetahuan guru tentang anak berkebutuhan khusus pada saat pretest dan posttest. Artinya, pelatihan ini efektif untuk meningkatkan pemahaman guru PAUD mengenai anak berkebutuhan khusus.
\end{abstract}

Kata Kunci: ABK, pendidikan khusus, PAUD, guru

\begin{abstract}
The importance of identifying the special needs possessed by children is a concern because it will have an impact on the selection and success of the Education program for children with special needs (CSN). The existence of comorbidities in each classification of special needs is a problem so that teachers must be given knowledge about various classifications of children with special needs, their characteristics, and education. There are many classifications of children with special needs. However, in this service, we focus on only a few classifications, namely autism, ADHD, and dyslexia. The service provides this knowledge to PAUD teachers in Bangkinang Kota District by conducting a pretest and posttest to measure the effectiveness of this training. The results of the analysis showed that the mean value of the pretest was 3.36 and the result of the post-test was 5.52 with a significance value of 0.000 . This shows that there is a significant difference in teacher knowledge about children with special needs at the pretest and posttest. This means that this training is effective in increasing PAUD teachers' understanding of children with special needs..
\end{abstract}

Keywords: SNC, special education, PAUD, teacher

\section{Pendahuluan}

Penyelenggaraan Pendidikan anak usia dini di Negara maju telah berlangsung lama sebagai bentuk pendidikan yang berbasis masyarakat (community besed education). Pendidikan Anak Usia Dini (PAUD) adalah jenjang pendidikan sebelum jenjang pendidikan dasar yang merupakan suatu upaya pembinaan yang ditujukan bagi anak sejak lahir sampai dengan usia enam tahun yang dilakukan melalui pemberian 
rangsangan pendidikan untuk membantu pertumbuhan dan perkembangan jasmani dan rohani agar anak memiliki kesiapan dalam memasuki pendidikan lebih lanjut, yang diselenggarakan pada jalur formal, nonformal, dan informal. Pendidikan anak usia dini merupakan salah satu bentuk penyelenggaraan pendidikan yang menitikberatkan pada peletakan dasar ke arah pertumbuhan dan 5 perkembangan, yaitu: perkembangan moral dan agama, perkembangan fisik (koordinasi motorik halus dan kasar), kecerdasan/kognitif (daya pikir, daya cipta), sosio emosional (sikap dan emosi) bahasa dan komunikasi, sesuai dengan keunikan dan tahap-tahap perkembangan sesuai kelompok usia yang dilalui oleh anak usia dini seperti yang tercantum dalam Permendiknas no 58 tahun 2009.

Anak usia tiga tahun pertama anak adalah usia emas. Hal ini sudah bukan informasi baru lagi dan anak pada usia ini menyerap informasi sebanyak-banyaknya. Berdasarkan pengetahuan ini pun makin banyak didengungkan mengenai pentingnya pendidikan anak usia dini. Perlu orang tua ketahui bahwa anak memiliki kemampuan yang perlu diasah sejak dini, karena dengan mereka memiliki berbagai kemampuan tersebut tentunya sudah dapat dibentuk sedari dini. Sayangnya banyak orangtua yang menganggap pendidikan anak usia dini tidak begitu penting, dengan alasan tidak ingin anaknya mengalami stres atau kehilangan masa bermain. Padahal, 70 persen pembentukan karakter manusia itu dimulai dari usia nol hingga 3 tahun. Sejak dini, anak-anak berhak mendapat saran pendidikan yang nyaman, penuh kasih sayang, dan dalam lingkungan mendukung. Pendidikan bagi anak usia dini adalah pemberian upaya untuk menstimulasi, membimbing, mengasuh dan pemberian kegiatan pembelajaran yang akan menghasilkan kemampuan dan ketrampilan anak. Pendidikan anak usia dini merupakan salah satu bentuk penyelenggaraan pendidikan yang menitik beratkan pada peletakan dasar ke arah pertumbuhan dan perkembangan fisik (koordinasi motorik halus dan kasar), kecerdasan, daya cipta, kecerdasan emosi, dan kecerdasan spiritual. Demikian juga halnya dengan anak luar biasa atau anak berkebutuhan khusus. Anak luar biasasecara ilmiah disebut sebagai berkebutuhan khusus. Hal ini masih disalahtafsirkan. Anak luar biasa selalu diartikan sebagai anak yang berkemampuan unggul atau berprestasi yang luar biasa. Padahal pengertian anak luar biasa juga mengacu kepada pengertian yaitu anak yang mengalami kelainan atau ketunaan, baik pada satu macam kelainan maupun lebih dari satu jenis kelainan (Geniofam, 2010).

Dunia pendidikan luar biasa seorang anak diartikan sebagai anak yang luar biasa jika anak tersebut membutuhkan perhatian khusus dan layanan pendidikan yang bersifat khusus oleh guru pendidik atau pembimbing khusus yang berlatar disiplin ilmu pendidikan luar biasa atau disiplin ilmu lainnya yang relevan dan memiliki sertifikasi kewenangan mengajar, mendidik, membimbing, dan melatih anak luar biasa.

Sebagaimana halnya anak pada umumnya, anak berkebutuhan khusus juga memerlukan Pendidikan yang layak bagi mereka sehingga Pendidikan tersebut diatur 
dalam Undang-Undang No. 20 Tahun 2003 tentang Sistem Pendidikan Nasional Pasal 32 menyebutkan bahwa :

"Pendidikan khusus (pendidikan luar biasa) merupakan pendidikan bagi peserta didik yang memiliki tingkat kesulitan dalam mengikuti proses pembelajaran karena kelainan fisik, emosional, mental, sosial".

Ketetapan Undang-Undang No. 20 Tahun 2003 tersebut bagi anak penyandang kelainan sangat berarti karena memberi landasan yang kuat bahwa anak berkelainan perlu memperoleh kesempatan yang sama sebagaimana yang diberikan kepada kepada anak normal lainnya dalam hal pendidikan dan pengajaran.

Memberikan kesempatan yang sama kepada anak berkelainan untuk memperoleh pendidikan dan pengajaran, berarti memperkecil kesenjangan angka partisipasi pendidikan anak normal dengan anak berkelainan. Untuk investasi jangka panjang dengan lahirnya para penyandang cacat yang terdidik dan terampil, secara tidak langsung dapat mengurangi biaya pos perawatan dan pelayanan kebutuhan seharihari. Di samping itu ada efek psikologis yaitu tumbuhnya motif berprestasi dan meningkatnya harga diri anak berkelainan, yang nilainya jauh lebih penting dan dapat melebihi nilai ekonomi. Kondisi yang konstruktif ini dapat memperkuat pembentukan konsep diri anak berkelainan.

Istilah "ketidakmampuan" (disability) dan "cacat" (handicap) dapat dipakai bersama-sama, namun kini kedua istilah itu dibedakan. Disability adalah keterbatasan fungsi yang membatasi kemampuan seseorang. Handicap adalah kondisi yang dinisbahkan pada seseorang yang menderita ketidakmampuan. Kondisi ini boleh jadi disebabkan oleh masyarakat, lingkungan fisik, atau sikap orang itu sendiri (Lewis dalam Santrock, 2008). Para pendidik lebih sering menggunakan istilaah "children with disabilities"(anak yang menderita gangguan/ketidakmampuan) ketimbang "disabled children" (anak cacat). Tujuannya adalah memberikan penekanan pada anaknya, bukan pada cacat atau ketidakmampuannya. Gearheart (1981) mengatakan bahwa seseorang anak dianggap berkelainan bila memerlukan persyaratan pendidikan yang berbeda dari rata-rata anak normal, dan untuk dapat belajar secara efektif memerlukan program, pelayanan, fasilitas dan materi khusus.

Dari sudut kebutuhan Pendidikan, Hallahan dan Kauffman (2006) memberikan pengertian bahwa siswa berkebutuhan khusus adalah mereka yang memerlukan pendidikan khusus dan pelayanan terkait, jika mereka menyadari akan potensi penuh kemanusiaan mereka. Pendidikan khusus diperlukan karena mereka tampak berbeda dari siswa pada umumnya dalam satu atau lebih hal berikut : mereka mungkin memiliki keterbelakangan mental, ketidakmampuan belajar atau gangguan atensi, gangguan emosi atau perilaku, hambatan fisik, hambatan berkomunikasi, autism, traumatic brain injury, hambatan pendengaran, hambatan penglihatan, atau special gifts or talents. Kekhususan yang relevan dari perbedaan cara belajar, membutuhkan instruksi yang berbeda dari yang umum diperlukan para siswa. Kekhususan mereka mencakup bidang sensori, fisik, kognitif, emosi, atau kemampuan bekomunikasi atau kombinasinya. 
Kekhususan bisa sangat berbeda dalam penyebab, tingkat keparahan, dampak bagi kemajuan pendidikan, dan dampak yang berbeda inipun bias tergantung dari usia seseorang, jenis kelamin, dan lingkungan hidupnya.

Pendidikan khusus/luar biasa oleh Hallahan dan Kauffman (2006) adalah instruksi yang di desain khusus untuk memenuhi kebutuhan-kebutuhan khusus. Materi, teknik mengajar, atau peralatan dan atau fasilitas khusus mungkin diperlukan. Pelayanan yang berkaitan mencakup transportasi khusus, asesmen psikologis, terapi fisik dan okupasional, treatmen medis, dan konseling diperlukan agar pendidikan khusus menjadi efektif. Tujuan penting yang paling utama dari pendidikan khusus adalah menemukan dan menitikberatkan kemampuan siswa berkebutuhan khusus.

Dalam Pendidikan khusus, identifikasi kebutuhan khusus merupakan hal yang paling krusial karena akan berkaitan dengan metode dan Teknik Pendidikan yang sesuai dengan jenis kebutuhan khusus anak. Tidak semua orang mampu mengidentifikasi kebutuhan khusus anak, bahkan ciri-ciri yang dimunculkan menunjukkan komorbiditas. Oleh karena itu, berdasarkan latar belakang keilmuan yang sesuai, kami membantu para guru untuk mampu mengidentifikasi anak berkebutuhan khusus dengan memberikan pengetahuan mengenai anak berkebutuhan khusus tersebut.

Pembedaan anak berkelainan dan tidak berkelainan dalam praktik kehidupan sehari-hari di kalangan orang awam tidak jarang mengalami kerancuan kriteria sehingga menetapkan "status" anak dalam katagori tertentu seringkali terjadi salah tafsir. Hal ini dikarenakan batas antara kondisi normal dan tidak normal sangat tipis. Misalnya seseorang yang sebelumnya dianggap bekelainan karena tanda-tanda yang menjadi acuan berkelainan tampak melekat pada dirinya, tetapi setelah melalui proses penanganan yang intensif ternyata tanda-tanda kelainan tersebut tidak tampak lagi pada dirinya. Contoh dari kondisi tersebut dapat dijumpai pada kasus seorang anak terbelakang semu. Akibat suatu peristiwa traumatik tertentu, secara mental ia tampak seperti anak terbelakang mental, namun setelah mendapat perawatan secara khusus tampak yang bersangkutan tidak lagi menunjukkan tanda-tanda sebagaimana yang dialami sebelumnya. Jadi keterbelakangan mental yang dialami anak selama ini bersifat semu karena tertutupnya arca kemampuan yang sebenarnya.

Kasus khusus yang lain menunjukkan bahwa seorang anak yang lahir dengan kondisi anggota tubuh tidak normal, misalnya tidak memiliki jari-jari tangan yang lengkap. Ketidaknormalan fisik tersebut, tidak membuat yang bersangkutan mengalami kesulitan melakukan kegiatan sehari-hari yang berkaitan dengan pemanfaat fungsi fisik, mental, dan penyesuaian sosial. Dengan kata lain, anak dapat melakukan aktivitas sebagaimana layaknya anak normal lainnya.

Setiap kelainan yang ada pada hakikatnya memiliki derajat tertentu. Gradasi kelainan dimulai dari tingkat yang paling berat hingga tingkat yang paling ringan. Pada ambang batas tertentu jarak anak yang berkelainan dengan tidak berkelainan tampak ada perbedaan yang mencolok. Menyinggung masalah derajat anak berkelainan 
dalam aspek tertentu, sebenarnya anak berkelainan macam apakah yang dikatagorikan sebagai anak berkelainan mendapatkan pendidikan khusus?

Kirk dalam Muhammad dan Muhammad (2008) menjelaskan tentang anak berkelainan yang dimasukkan ke dalam katagori perlu layanan khusus, yaitu "....who deviates from the average or normal child in mental, or social charactheristics ti such an extent that be requires a modification of school practices, or special educational srvices in order to develop to his maaximum capacity". Pendapat yang hampir sama tentang anak keberlainan dikemukakan oleh Hallah dan Kaufman (1991), yaitu "....those who require special education anad related services if they are to realize their full human potential".

Implikasi kedua pernyataan tersebut bahwa layanan pendidikan khusus (Student with special needs) hanya diberikan kepada anak yang memiliki hambatan untuk meniti tugas perkembangannya, disebabkan oleh kelainan dalam aspek fisik, mental, dan sosial emosi. Dengan pemberian layanan pendidikan khusus yang relevan dengan kebutuhannya, sisa potensi yang dimiliki oleh anak berkelainan diharapkan dapat berkembang secara optimum.

Kesalahan masyarakat dalam memahami anak luar biasa salah satu penyebabnya adalah kurangnya bacaan yang representatif dan aktual tentang anak luar biasa, faktorfaktornya, klasifikasinya, dan karakteristiknya dari masing-masing jenis anak yang disebut luar biasa. Dalam dunia pendidikan luar biasa dewasa ini anak berkebutuhan khusus diklasifikasikan atas beberapa kelompok sesuai dengan jenis kelainan anak, kalisfikasi tersebut mencakup kelompok anak yang mengalami keterbelakangan mental, ketidakmampuan belajar, gangguan emosional, kelainan fisik, kerusakan atau gangguan pendengaran, kerusakan atau gangguan pengelihatan, gangguan bahasa dan wicara, dan kelompok anak yang berbakat (Muhammad, 2008).

Salah satu yang disebut anak luar biasa adalah anak yang mengalami kelainan yang meliputi fungsi intelektual umum dibawah rata-rata sehingga dalam proses pendidikannya harus dilakukan secara individual. Anak seperti ini disebut tuna grahita yaitu anak yang lamban dalam fungsi intelektual yaitu IQ 70 kebawah berdasarkan tes inetelegensi baku dan terjadi pada masa perkembangan, yaitu antara masa konsepsi hingga 18 tahun (Geniofam, 2010). Secara garis besar aspek-aspek yang diperlukan guru dalam merancang dan melaksanakan kegiatan pembelajaran meliputi pengelolaan ruang belajar (kelas) pengelolaan siswa dan pengelolaan kegiatan. Pembelajaran berupaya mengubah masukan berupa siswa yang belum terdidik menjadi siswa terdidik, siswa yang belum memiliki pengetahuan tentang sesuatu, menjadi siswa yang mememiliki pengetahuan. Demikian pula siswa yang memiliki sikap, kebiasaan atau tingkah laku yang belum mencerminkan eksistensi dirinya sebagai pribadi baik atau pasif menjadi siswa yang memiliki sikap kebiasaan dan tingkah laku yang baik.

Berdasarkan pertimbangan frekuensi munculnya kebutuhan khusus dan keterbatasan waktu, maka kami memilih beberapa jenis kebutuhan khusus yang kami paparkan kepada guru, diantaranya adalah Autis, Attention Deficit Hyperactive Disorder (ADHD), dan Diskleksia serta tentang Pendidikan khusus. 
Autism Syndrome merupakan kelainan yang disebabkan adanya hambatan pada ketidakmampuan berbahasa yang diakibatkan oleh kerusakan pada otak. Gejala-gejala autism menurut Delay \& Deinaker (1952) dan Marholin \& Philips (1976) dalam Delphie (2006) antara lain; (1) Senang tidur bermalas-malasan atau duduk menyendiri dengan tampang acuh, muka pucat, dan mata sayu dan selalu memandang ke bawah, (2) Selalu diam sepanjang waktu, (3) Jika ada pertanyaan terhadapnya, jawabannya sangat pelan dengan nada monoton, kemudian dengan suara yang aneh akan menceritakan dirinya dengan beberapa kata kemudian diam menyendiri lagi, (4) Tidak pernah bertanya, tidak menunjukkan rasa takut dan tidak menyenangi sekelilingnya, (5) Tidak tampak ceria, (6) Tidak peduli terhadap lingkungannya, kecuali terhadap benda yang disukainya.

Secara umum anak autis mengalami kelainan dalam berbicara, kelainan fungsi saraf dan intelektual, Hal tersebut dapat terlihat dengan adanya keganjilan perilaku dan ketidakmampuan berinteraksi dengan lingkungan sekitarnya.

Hyperactive bukan merupakan penyakit tetapi suatu gejala atau symptoms. (Batshaw \& Perret, 1986) symptoms terjadi disebabkan oleh factor-faktor brain damage, an emotional disturbance, a hearing deficit or mental retardaction. Dewasa ini banyak kalangan medis masih menyebut anak hiperaktif dengan istilah attention deficit disorder (ADHD) (Solek, P. 2004)

Kesulitan belajar membaca sering disebut juga disleksia (dyslexia). Perkataan disleksia berasal dari bahasa Yunani yang artinya "kesulitan membaca."Ada nama-nama lain yang menunjuk kesulita belajar membaca, yaitu corrective readers dan remedial readers; sedangkan kesulitan belajar membaca yang berat sering disebut aleksia (alexia).

Menurut Mercer (dalam Abdurrahman, 1999) ada empat kelompok karakteristik kesulitan belajar membaca, yaitu berkenaan dengan (1) kebiasaan membaca, (2) kekeliruan mengenal kata, (3) kekeliruan pemahaman, dan (4) gejala-gejala serbaneka.

Anak berkesulitan belajar membaca sering memperlihatkan kebiasaan membaca yang tidak wajar. Mereka sering memperlihatkan adanya gerakan-gerakan yang penuh ketegangan seperti mengernyitkan kening, gelisah, irama suara meninggi, atau menggigit bibir. Mereka juga sering memperlihatkan adanya perasaan tidak aman yang ditandai dengan perilaku menolak untuk membaca, menangis, atau mencoba melawan guru. Pada saat membaca mereka sering kehilangan jejak sehingga sering terjadi pengulangan atau ada baris yang terlompat sehingga tidak dibaca. Mereka juga sering memperlihatkan adanya gerakan kepala ke arah lateral, ke kiri atau ke kanan, dan kadang-kadang meletakkan kepalanya pada buku.Anak berkesulitan belajar membaca juga sering memagang buku bacaan yang terlalu menyimpang dari kebiasaan anak normal, yaitu jarak antara mata dan buku bacaan kurang dari 15 inci. Anak berkesulitan belajar membaca sering mengalami kekliruan dalam mengenal kata. Kekeliruan jenis ini mencakup penglihatan, penyisipan, penggantian, pembalikan, salah ucap, pengubahan tempat, tidak mengenal kata, dan tersentak-sentak. 
Myklebust dan Johnson seperti dikutip Hargrove dan Poteet (dalam Abdurrahman, 1999) mengemukakan beberapa cirri anak berkesulitan belajar sebagai berikut : (1) Mengalami kekurangan dalam memori visual dan auditoris, kekurangan dalam memori jangka pendek dan jangka panjang, (2) Memiliki masalah dalam mengingat data seperti mengingat hari-hari dalam seminggu, (3) Memiliki masalah dalam mengenal arah kiri dan kanan, (4) Memiliki kekurangan dalam memahami waktu, (5) Jika diminta menggambar orang sering tidak lengkap, (6) Miskin dalam mengeja, (7) Sulit dalam menginterpretasikan globe, peta, atau grafik, (8) Kekurangan dalam koordinasi dan keseimbangan, (9) Kesulitan dalam belajar berhitung, dan (10) Kesulitan dalam belajar bahasa asing.

Dalam menanamkan pengetahuan dan kemampuan mengidentifikasi anak berkebutuhan khusus beserta pendidikannya, pengabdi menggunakan model konstruktivisme, yaitu pengabdi lebih berperan sebagai fasilitator dan mediator pembelajaran. Penekanan tentang belajar dan mengajar lebih berfokus terhadap suksesnya peserta mengorganisasi pengalaman mereka. Menurut Werrington (dalam Suherman, 2003), menyatakan bahwa dalam kelas konstruktivis seorang guru tidak mengajarkan kepada anak bagaimana menyelesaikan persoalan, namun mempresentasikan masalah dan mendorong siswa untuk menemukan cara mereka sendiri dalam menyelesaikan permasalahan. Ketika siswa memberikan jawaban, guru mencoba untuk tidak mengatakan bahwa jawabannya benar atau tidak benar. Namun guru mendorong siswa untuk setuju atau tidak setuju kepada ide seseorang dan saling tukar menukar ide sampai persetujuan dicapai tentang apa yang dapat masuk akal siswa.

Dalam pelatihan ini, guru (peserta) diberdayakan oleh pengetahuannya yang berada dalam diri mereka. Mereka berbagi strategi dan penyelesaian, debat antara satu dengan lainnya, berfikir secara kritis tentang cara terbaik untuk menyelesaikan setiap masalah. Beberapa prinsip pembelajaran dengan pendekatan konstruktivis diantaranya bahwa observasi dan mendengar aktivitas dan pembicaraan matematika siswa adalah sumber yang kuat dan petunjuk untuk mengajar, untuk kurikulum, untuk cara-cara dimana pertumbuhan pengetahuan siswa dapat dievaluasi.

Berikut ini akan dikemukakan ciri-ciri pembelajaran yang konstruktivis menurut beberapa literatur yaitu sebagai berikut; (1) Pengetahuan dibangun berdasarkan pengalaman atau pengetahuan yang telah ada sebelumnya, (2) Belajar adalah merupakan penafsiran personal tentang dunia, (3) Belajar merupakan proses yang aktif dimana makna dikembangkan berdasarkan pengalaman, (4) Pengetahuan tumbuh karena adanya perundingan (negosiasi) makna melalui berbagai informasi atau menyepakati suatu pandangan dalam berinteraksi atau bekerja sama dengan orang lain.

\section{Metode}

Kelompok sasaran dalam pengabdian ini adalah seluruh guru PAUD di Kecamatan Bangkinang kota yang tidak memiliki latar belakang pendidikan PG PAUD sebanyak 23 
orang yang ditentukan oleh UPTD Disdikpora Bangkinang. Seluruh guru yang ikut dalam pelatihan ini adalah guru perempuan. Data guru tersebut disajikan pada tabel berikut:

Tabel 1. Deskripsi Subjek Pengabdian

\begin{tabular}{|c|c|c|c|}
\hline No & Nama (Inisial) & Pendidikan Terakhir & Tempat Tugas \\
\hline 1 & $\mathrm{TN}$ & SMA & TKIT Khoddijah Al-Kubro \\
\hline 2 & ID & SMA & TKIT Khoddijah Al-Kubro \\
\hline 3 & ND & SMA & TKIT Khoddijah Al-Kubro \\
\hline 4 & DNB & SMA & TKIT Khoddijah Al-Kubro \\
\hline 5 & EL & SMA & Adzkiyah \\
\hline 6 & SS & SMA & Adzkiyah \\
\hline 7 & EE & SMA & TK Al-Fitrah Ridan \\
\hline 8 & ER & SMA & TK Al-Fitrah Ridan \\
\hline 9 & FD & SMA & TK Al-Fitrah Ridan \\
\hline 10 & SI & SMA & Tahfizh Rabbani \\
\hline 11 & UK & SMA & Tahfizh Rabbani \\
\hline 12 & ME & SMA & TKIT Permata Hati \\
\hline 13 & FR & SMA & TKIT Permata Hati \\
\hline 14 & RT & SMA & TK Pembina \\
\hline 15 & NA & SMA & TK Pembina \\
\hline 16 & DD & SMA & Mutiara Bunda \\
\hline 17 & DY & SMA & Mutiara Bunda \\
\hline 18 & EM & SMA & PAUD Taqifa \\
\hline 19 & GL & SMA & PAUD Taqifa \\
\hline 20 & SY & SMA & PAUD Insan Kamil \\
\hline 21 & DW & SMA & PAUD Insan Kamil \\
\hline 22 & SK & SMA & PAUD Perdana \\
\hline 23 & LA & SMA & PAUD Perdana \\
\hline
\end{tabular}

Metode pelaksanaan pengabdian menggunakan metode pelatihan dengan model konstruktivisme dimana narasumber membangun pengetahuan berdasarkan pengalaman guru, diskusi dalam kelompok, Latihan identifikasi ABK dan Pendidikan yang tepat. Sebelum pelatihan dimulai peserta diberikan pretest untuk menguji kemampuan dan pengetahuan para guru PAUD mengenai anak berkebutuhan khusus dan pendidikannya. Dan setelah pelatihan maka dilakukan posttest yaitu untuk mengetahui sejauhmana kemampuan para guru dalam meguasai materi pelatihan. 


\section{Hasil dan Pembahasan}

Pengabdian masyarakat ini dilakukan selama satu hari, dari 33 orang guru yang ditentukan oleh UPTD Disdikpora Bangkinang hanya 23 orang guru PAUD yang hadir. Pelatihan dimulai dengan pengarahan yang diberikan oleh Kepala UPTD Disdikpora Bangkinang dan Kepala Sekolah SLB Bangkinang selaku pembicara ekternal. Kegiatan berjalan dengan lancar mulai pukul 08.00-17.00 WIB.

Peserta pelatihan menunjukkan antusias terhadap materi yang dikemukakan oleh narasumber yang terlihat dari banyaknya peserta yang bertanya. Hasil pretest dan posttest menunjukkan bahwa terdapat peningkatan pengetahuan mengenai anak berkebutuhan khusus, deteksi dini dan asesmen anak berkebutuhan khusus. Hal tersebut terlihat dari nilai rata-rata pre test dan post test yang ditunjukkan. Hasil rerata nilai pretest adalah 3,36 dan hasil post test adalah 5,52 dengan nilai signifikansi 0,000. Hal tersebut menunjukkan bahwa terdapat perbedaan yang signifikan mengenai pengetahuan guru tentang anak berkebutuhan khusus pada saat pretest dan posttest. Artinya, pelatihan ini efektif untuk meningkatkan pemahaman guru PAUD mengenai anak berkebutuhan khusus.

Jika dilihat setiap aspek: aspek pengetahuan mengenai anak berkebutuhan khusus, pendidikan anak berkebutuhan khusus, disleksia, autis, ADHD diperoleh gambaran sebagai berikut:

Tabel 2. Analisis Per aspek Pengetahuan Anak Berkebutuhan Khusus

\begin{tabular}{lccc}
\hline Aspek & Pretest & Posttest & Selisih \\
\hline Pengetahuan mengenai Anak Berkebutuhan Khusus & 25 & 57 & 32 \\
Pengetahuan mengenai Pendidikan Anak & 8 & 17 & 9 \\
Berkebutuhan Khusus & 30 & 39 & 9 \\
Pengetahuan mengenai disleksia & 10 & 13 & 3 \\
Pengetahuan mengenai Autis & 3 & 1 & 2 \\
Pengetahuan mengenai ADHD & & & \\
\hline
\end{tabular}

Tabel di atas menunjukkan seluruh aspek pengetahuan mengenai Anak Berkebutuhan Khusus mengalami kenaikan terutama mengenai pengetahuan mengenai anak berkebutuhan khusus, namun pada pengetahuan mengenai ADHD menunjukkan sedikit kenaikan.

\section{Diskusi}

Pelatihan dengan pendekatan konstruktif dapat meningkatkan pengetahuan dan pemahaman mengenai materi yang menjadi target pelatihan. Hal ini tentu saja sangat diperlukan dalam dunia pendidikan agar masyarakat dapat memahami konteks dari sumber yang jelas. Pelatihan-pelatihan seperti sangat diperlukan bagi pendidik terutama yang belum mendapat gelar sarjana khususnya dalam bidan pendidikan anak usia dini dalam konteks pelatihan ini. 
Pemahaman guru PAUD mengenai anak berkebutuhan khusus masih sangat minim sehingga perlu diberi wawasan mengenai hal tersebut mengingat anak berkebutuhan khusus juga memiliki hak untuk mendapatkan pendidikan. Amanat hak atas pendidikan bagi penyandang kelainan atau ketunaan ditetapkan dalam Undang-Undang No. 20 Tahun 2003 tentang Sistem Pendidikan Nasional Pasal 32 disebutkan bahwa : "pendidikan khusus (pendidikan luar biasa) merupakan pendidikan bagi peserta didik yang memiliki tingkat kesulitan dalam mengikuti proses pembelajaran karena kelainan fisik, emosional, mental, sosial".

Memahami berbagai jenis anak berkebutuhan khusus tidak mudah bagi guru, perlu pengulangan dan waktu yang lebih panjang dan juga banyak sekali jenis-jenis anak berkebutuhan khusus diantaranya retardasi mental, ADHD, Autis, Gangguang belajar, Asperger, dan lain-lain. Namun yang paling sering muncul pada saat ini adalah retardasi mental, ADHD, Autis dan Gangguan Belajar (Disleksia).

Hasil pretest dan posttest kegiatan ini menunjukkan bahwa pemahaman peserta mengenai autis dan ADHD tidak mengalai kenaikan yang sangat signifikan. Hal ini dapat disebabkan karena peserta belum familiar dengan istilah-istilah yang digunakan dan materi mengenai ADHD dan autis sangat banyak termasuk klasifikasi dan jenisnya. Selain itu, ciri-ciri dari klasifikasi kedua gangguan tersebut terkadang memiliki kormobiditas. Maksudnya ciri yang sama terdapat pada kedua gangguan tersebut seperti impulsifitas. Anak dengan autistik dan ADHD sama-sama menunjukkan impulsifitas seperti berteriak dan kesulitan dalam mengikuti instruksi (Nevid, Rathus dan Greene, 2005).

\section{Simpulan}

Pelatihan ini efektif untuk meningkatkan pengetahuan guru PAUD mengenai pengetahuan tentang anak berkebutuhan khusus, namun praktek untuk mendeteksi anak berkebutuhan khusus perlu dilakukan meskipun dalam pelatihan ini, peserta sudah diberikan wawasan mengenai identifikasi anak berkebutuhan khusus beserta pengetahuan dalam mengatasi atau menghadapi anak berkebutuhan khusus.

Keterbatasan waktu merupakan salah satu kendala dalam pelatihan ini karena tidak semua jenis anak berkebutuhan khusus dapat diberikan kepada peserta hanya jenis-jenis yang paling sering muncul seperti disleksia, autis dan retardasi mental sehingga disarankan penambahan waktu dalam pelaksanaan kegiatan, paling tidak untuk 3 hari, peserta diberikan kesempatan untuk praktik dalam melaksanakan mengidentifikasi anak berkebutuhan khusus.

\section{Referensi}

Abdurrahman, M. (1999). Pendidikan bagi Anak Berkesulitan Belajar. Jakarta: Rineka Cipta.

Batshaw \& Perret. (1986). Anak Berkebutuhan Khusus. http://bintangbangsaku.com/cgi-sys/suspendedpage.cgi 
Delphie, Bandi. (2006). Pembelajaran Berkebutuhan dalam Setting Pendidikan Inklusi. Bandung : Refika Aditama

Gearhart, B.R. (1981). Earning Disabilities: Educational Strategies. British: Amazon

Geniofam. (2010). Mengasuh \& Mensukseskan Anak Berkebutuhan Khusus. Jogjakarta: Gerai Ilmu

Hallahan, D.P. \& Kauffman, J.M. (2006). Exceptional Learners: Introduction to Special Education 10th ed. USA: Pearson.

Muhammad, Ali., Muhammad, Asrori. (2008) . Psikologi Remaja Peserta Didik, Jakarta: Bumi Aksara.

Nevid, J. S., Rathus, S. A., \& Greene, B. (2005). Psikologi abnormal. Jakarta: Erlangga.

Santrock, J.W. (2008). Psikologi Pendidikan. Jakarta: Prenada Media Group

Solek, Purboyo. (2004). Rett Syndrom in Childhood: The Clinical Characteristic. Pedriatica Indonesiana. Vol. 44 No. 4. DOI: https://doi.org/10.14238/pi44.4.2004.160-4

Suherman, Erman dkk. 2003. Strategi Pembelajaran Matematika Kontemporer. Bandung: PT Remaja Rosdakarya. 